\title{
Anxiolytics, Antidepressants and Autogenous training in the therapy of burning mouth syndrome
}

\author{
Josipa Sanja Gruden Pokupec ${ }^{1}$, Lidija Gavić ${ }^{2}$, Mladen Klemenčić ${ }^{3}$,Helena \\ Matic $^{4}$ \\ 1) Dental Clinic, Perkovceva 3, Zagreb, University of Medicine, Soltanska 2 in Split, Croatia \\ 2) University of Medicine, Soltanska 2 in Split, Croatia \\ 3) Dental Clinic, Perkovceva 3, Zagreb,Croatia \\ 4) “Krka”d.o.o.,Zagreb,Croatia
}

\begin{abstract}
It is well known that many diseases of our system can cause various pathological changes and symptoms. Psychical disorders are considered to be the main cause of changes in the oral cavity. The most frequent psychical disturbances associated with the symptoms are: depression, anxiety and stress.
\end{abstract}

Methods: The research was conducted by means of psychological questionnaires resting depression and anxiety and we tried to objectivize the burning symptom by means of a VAS scale (visual analogous scale).

Results: The results we obtained suggest that by treating psychical disturbances we might obtain significant improvement in treating symptoms in the oral cavity. The results have shown that there is a significant rise in negative findings in both psychological tests and within the mouth. Anxiety tests show primarily negative values: in the first group: $90 \%$ of the respondents, in the second group $73.3 \%$, in the third group $83.3 \%$ and in the fourth group $56.7 \%$ of the respondents. The depression test has shown that the first group of respondents displayed mainly borderline values - 53.3\%, without positive values, while negative values have risen to $46.7 \%$. The second group has increased its negative values to $96.7 \%$ of the respondents, without any positive values and with a few borderline findings: 3.3\%. The third group displayed mainly negative values (76.1\%) and borderline values (23.3\%), with no positive findings.

Conclusion: Antidepressants and anxiolytics have a prominent role in the therapy of stomatopyrosis. Autogenic training - a psychotherapeutic anxiolytic technique - is the therapy of choice as far as stomatopyrosis is concerned, as it both eliminates the problems and emotionally rehabilitates the patient.

Key Words: anxiolytics, antidepressants, burning mouth symptoms and psychologycal tests

\section{INTRODUCTION:}

Apart from being local and systemic, etiological factors of stomatopyrosis are quite often psychogenic. Psychogenic factors are associated with war and post-war situations which are currently specific for Croatia. In such circumstances, the whole organism is subjected to stressful situations of psychical traumas, which is being reflected in the following symptoms: depression, anxiety, adaptability and emotional stability. Scientific research and clinical investigations have proven that psychogenic factors cause the burning mouth sensation. Psychogenic factors are various mental states which result in stomatopyrosis. Various psychological states of stress, neurosis and psychosis lead to the disturbances in the whole organism, primarily the base of the vegetative nerve system, which leads to the dryness of the mouth, which again facilitates the burning syndrome. Due to ample innervations of the mouth, an increase in the impulses caused by various stressful events can result in the 'burning mouth' syndrome. There are many different mechanisms which lead to this oral symptom. One of the mechanisms leading to the occurrence of the burning sensation with changeable personalities is their fixation on one part of their organism. The most common fixation is the oral one, which means that the patients go back to the time when they were protected by their mothers or fathers. This is particularly characteristic for older population, as they are the ones who go back to their childhood, so we often say that an elderly person is 'childish'. The most frequent fixations referring to oral system are tooth aching, tongue burning and similar symptoms.

Once we have established a psychogenic factor, we have to prove the psychopharmatics which facilitate healing of the patients suffering from stomatopyrosis. Apart from psychical factors, psychosocial factors have significant effects on the emergence of pain on the face and orofacial region.Feinmann and Haris (1) have shown that atypical pain on the face can be associated with a life marked with stressful events and long-lasting problems. 
Hammaren and Hugoson (2) have proved that majority of people with stomatopyrosis have experienced stressful situations in their lives, such as stillborn children and handicapped children. Respondents suffering from stomatopyrosis have reported various forms of long-lasting social problems. The same was confirmed by Domb et al. (3).Hamf et al. (4) showed that people suffering from stomatopyrosis have a mild, moderate or serious mental disorder. They also managed to establish that people with stomatopyrosis often stress their own psychical problems.Lamb et al. (5) proved that a psychological factor is present in etiology of stomatopyrosis with the majority of patients suffering from stomatopyrosis. People with stomatopyrosis are indecisive patients, but they still prefer their own decisions. They tend to like changes. Their possessiveness and feeling of guilt are often associated with their being shy.

They restrain from complaining, but are submissive to a firm advice and professional help. Respondents with stomatopyrosis are kind and sensitive people.Brody and Nesbitt (6) have in their research confirmed that emotional factors are very important in the emergence of stomatopyrosis.Browing et al. (7) claims that majority of respondents with stomatopyrosis differ from the control group in that that they are more concerned about their own bodily functions, they are depressed, emotionally blunt, angry, distrusting, anxious and socially ostracized. They suggest that stomatopyrosis could be a common expression of reactive or exogenic depression which cause external stress, such as loneliness and professional care. These findings were confirmed by means of the Minnesota multiphase test.Gruden et al (8) established that people suffering from stomatopyrosis are often more depressed and anxious than the control group.Lamey and Lamb (9) pointed out that mental disturbances are one of the main etiological factors of stomatopyrosis, the most important being depression, anxiety and cancerophobia.Van der Ploeg et al. (10) studied people with stomatopyrosis by means of 4 questionnaires, the basis of whose psychiatric diagnoses were depression, anxiety and the tendency for neuroses. Psychical stress which is associated with the occurrence of stomatopyrosis is related to feelings of loss caused by death or separation. Schoenberg et al. (11) indicated the results of clinical testing of depression with people suffering from stomatopyrosis, which are to be taken in further research.Lamey and Lamb (9) claim that anxiety is one of the characteristic symptoms with people suffering from stomatopyrosis.

Basket et al. (10) concluded that anxiety and cancerophobia characteristic for hypochondriacs result in stomatopyrosis.Hamf et al. (4) claim that there is a link between psychogenic factors and organic disturbances. Oral galvanism and mental disturbances are quite common with people suffering from stomatopyrosis.Lamb (5) used Cately 16PF questionnaire to prove the existence of psychical factors in the etiology of stomatopyrosis. Their results have shown that depression and anxiety are the most common psychological factor with people suffering from stomatopyrosis. Lamey and Lamb (9), having used depression and anxiety questionnaires, concluded that anxiety is more common than depression with people suffering from stomatopyrosis.

Browing et al. (7) examined people suffering from chronic pain in their mouths with an identified organic cause. They studied respondents suffering from stomatopyrosis by means of psychiatric interviews and questionnaires on their general health condition. Respondents suffering from stomatopyrosis were proved to have psychiatric disturbances - anxiety, depression, and a positive psychiatric history.Rojo et al. (13) conducted psychological testing on the respondents suffering from stomatopyrosis, alongside with a control group. Their research was focused on somatization, phobias, paranoia and psychosis and it showed that patients with stomatopyrosis suffer from one or more of these.Jerlang et al. (14) have established that stomatopyrosis may be a result of a complex dynamics, from hysteric conversions to mental separation ('narcissistic nucleus'). What we talk about is actually alexithymia.Coles et al. (15) believes that people suffering from stomatopyrosis have hidden energy as a psychical disturbance, as this is what the test he conducted revealed.

Domb and Chole (3) studied the possibility of cancerophobia being a mental etiological factor with respondents suffering from stomatopyrosis and the results he obtained showed a high percentage of the interrelatedness between cancerophobia and stomatopyrosis.Greenberg et al. $(16,17,18)$ concluded that psychotherapy and psychopharmacotherapy are very successful in treating BMS which has occurred as a result of a mental disturbance.Botha (19) dealt with people suffering from stomatopyrosis in whose etiology there was a psychogenic factor. He concluded that psychotherapy and psychopharmacotherapy gave excellent results.

Klein $(20,21)$ noticed the emergence of anxiety with a mother and child, which was successfully treated by psychotherapy.Cashdan (22) concluded that psychotherapy has to be used not only with people who admit they suffer from psychical disturbances, but with the ones who deny their problems, having claimed that psychotherapy obtains excellent results.Blate and Ford (23) established that psychotherapy gives best results with people suffering from stomatopyrosis whose cause is psychogenic. The same was confirmed by Feidman (68). 
Hamilton (24) believes that personality of the psychotherapist is essential for the success of any psychotherapy, and thus for the success of psychotherapy of people suffering from stomatopyrosis.Spillius (25) has shown a psychogenic disturbance of the mother suffering from stomatopyrosis, which 'passed on' her daughter, in which psychotherapy conducted on the mother gave excellent results.Some authors have reported on a combined psychiatric therapy.Malan (26) et al. established that psychotherapy gives better results with patients suffering from stomatopyrosis than some other techniques.

Grushka et al. (27) studied the use of Clonazepam in the therapy against pains in the oral cavity and concluded that the result is successful provided the pain is caused by psychogenic factors.Eli et al. $(28,29)$ applied psychiatric/psychological treatment on people with mental disturbances and stomatopyrosis; very soon, the situation improved.Hondenhove et al. (30) studied the use of $50 \mathrm{mg}$ sertraline with people suffering from stomatopyrosis and depression. A 3-week therapy with this drug resulted in disappearance of the pain and depression.Grohol (32) claims that psychotherapy is the therapy of choice with people suffering from stomatopyrosis and depression.

Antonuccio (33) thinks that depression and stomatopyrosis can be eliminated by means of combined therapies. Wexler et al. (34) researched the use of psychopharmacs, psychotherapy and combined therapy on 100 respondents divided into 3 groups. The results have shown that combined therapy gave the best results with stomatopyrosis. Antonuccio (35) confirmed his own assumptions and claims that psychotherapy is the best treatment with people suffering from stomatopyrosis and depression.Karon et al. (36) believes that combined therapy gives better results with stomatopyrosis.'Burning mouth' syndrome is a state characterized by a sensation of heating and burning in the mouth, regardless the normal mucosa. Stomatopyrosis is a term for an unpleasant sensation of burning and pain in the oral mucosa of different intensity and duration with paresthetic pains and painful sensations which occur alongside an unpleasant taste, and the presence of xerostomy (38). Etiological factors of stomatopyrosis are divided into local, systemic and psychogenic.

Local etiological factors are various stimuli which can be found in the oral cavity.These are: mechanic irritation of oral mucosa and dental treatment against mechanical irritations, particularly problems with mobile dentures, followed by infections of the mouth of bacterial or fungal etiology, dysfunctional TMJ and disorders in the function of the salivary glands.Nater et al. (39) established that people suffering from stomatopyrosis have more candidae and coli bacteria than the ones in the control group, where stomatopyrosis wasn't present.Katz et al. (40) concluded that infections by fusospyrochetes are more common with people suffering from stomatopyrosis.Maresky et al. (41) concluded that people with stomatopyrosis often suffer from gingivitis and periodontitis.

James et al. (31) found out that local allergic reactions accompanied with burning sensation within the oral cavity are reaction to mercury in amalgam fillings.Luc, Tourne and Fricton (37) established that the burning sensation may be an allergic reaction to food preserves, such as sorbic acid, nicotine acid, propylene glycol and ingredients of instant coffee.Kabeek et al. (43) concluded that stomatopyrosis can occur with people allergic to the denture compounds, such as acrylate, although it is well known that it happens very rarely and that in that case stomatopyrosis would be accompanied with clinical pathological signs of allergies. This was confirmed by Thomson et al. (44), who concluded that burning isn't caused by acrylic denture, regardless the discomfort caused by this symptom. Systemic diseases may cause oral diseases with changes which may as well be pathological. Symptoms of stomatopyrosis in their base may have different diseases and deficiencies in the organism, such as the lack or insufficiency of hormones, lack in nutritional elements, or some immunological, gastrointestinal disorders, neurological diseases, blood-related diseases and coronary disorders and certain drugs.Epstein et al. (45) published the study in which they examined people suffering from stomatopyrosis who were taking antibiotics. Their results were positive as far as stomatopyrosis is concerned.Glass et al. (46) believe that some drugs cause stomatopyrosis, such as tricyclic antidepressants, phenodiazepine, benzodiazepine derivatives, Monoamine oxidaze (MAO) inhibitor and antihistamines. Maresky et al. (41) confirmed that the intake of some drugs results in the reduction of salivation, which facilitates the burning sensation.

\section{ANTIDEPRESSANTS AND ANXIOLYTICS}

A lot of attention has been lately given to psychogenic factors facilitating the emergence of stomatopyrosis. Due to the presence of various psychical disturbances with people suffering from stomatopyrosis, treatment directed towards the symptoms in the mouth has proven insufficient - in order to obtain better results, it is necessary to apply psychofarmacotherapy and psychotherapy.

Psychopharmatics used in this research belong to the group of antidepressants and anxiolytics. 


\section{ANTIDEPRESSANTS}

Antidepressants belong to the group of psychotropic or psychoactive drugs. Psychotropic drugs change the chemical-transmission system which in synapses with axon terminals of a neuron transmits stimuli to the dendrites of the neighbouring neuron through the synaptic cleft. Drugs such as acetylcholine, dopamine and other antidepressants. Appropriate chemical compounds will enable a direct impact on the creation, storage, releasing and bonding with the receptors of these active substances. Antidepressants prevent new active storage of released adrenalin in cellular depots. This activity facilitates the strengthening of the effects of adrenaline and noradrenaline, antagonizing antihypertensives and cardiotoxicity while overdosing. Antidepressants have both anticholinergic and antiserotonin activity. They are easily resorbed and metabolized in the liver. Side effects associated with antidepressants include anticholinergic effect such as dryness of the mouth, risk with patients suffering from glaucoma, prostate growth, orthostatic hypotension, tremor, hallucinations, dizziness, excitation, palpitation, epilepsy, jaundice and cardiac risks.Antidepressants facilitate the activity of catecholamine, adrenalin and noradrenalin. They are used 2 to 3 times a day, depending on the level of depression. The drug is to be taken for at least 6 months, the first results visible after a week (47).

\section{ANXIOLYTICS}

Anxiolytics are substances which depress the central nervous system. The most important indication requiring the implementation of benzodiazepine are conditions characterized by anxiety and sleeping disorders. Due to different distribution of benzodiazepine receptors in the brain, it is possible to use both anxiolytics and hypnotics, which do not have to overlap, which, naturally, depends on the dosage of the drug.

There are three groups of anxiolytics:

[1] benzodiazepines

[2] beta-adrenergic blockers

[3] antidepressants with sedating effect.

Benzodiazepines have hypnotic, sedating, anxiolytic and anticonvulsive effects. They bond to specific receptors which remain undefined and increase the effect of gama-aminobutric acid which influences the opening of the channels of chloride ions into the cell. They have a strong impact on the reticular activating system of the brain, limbic system, systems of gratitude and punishment and on the hypothalamus. They prolong the sleeping process.There are benzodiazepines which have opposite effects, called reversed agonists. Benzodiazepines are used as drugs in the treatment of anxiety, panic attacks, insomnia, somnambulism and epilepsy. They are taken three times a day.There are two types of benzodiazepines: nordiazepam and oxazepam, as well as nitrobenzodiazepines and triazolobenzodiazepines.Nordiazepam group includes benzodiazepines which metabolize into N-dezmetildiazepam. Their characteristics is the creation of hydroxylation, which prolong the effects to 40 hours, and are because of that taken once a day. The oxazepam group, due to active metabolites go on to original benzodiazepine, which means that its duration is shorter than 24 hours. Nitrobenzodiazepines are characterized by inactivation via nitro group, from 24 to 48 hours. Triazolobenzodiazepines have a triazol ring and together with similar group of imidazobenzodazepins metabolizes in oxidative reactions. They hydroxylate before they turn into glucoronidase.

The mechanism of the benzodiazepine activity was mentioned at the beginning of the text.Clinical implementation of benzodiazepine include treatment of epileptics, phantom pain and intermittent dystonic tremors and tardive distortion, and later side effects of neuroleptics. Toxicity of benzodiazepines is very small. The most important side effect is addiction and tolerance. The range between the effective dose and the dose causing adverse effects is very small. Side effect includes sedation, dizziness, ataxia (falls and fractures with elderly people), anterograde amnesia and dysarthria.In general, in the treatment of anxiety, benzodiazepines have sedative effects - they relax and cause myorelaxation and decreased alertness and hypervigilance. Results are obtained after a one-month intake.Dosage of benzodiazepine is small in the beginning, and it is gradually being increased until the optimal dose is achieved. Because of the possibility of becoming addicted, it is recommended that the drug be taken for maximum 6 months (47).

\section{AUTOGENIC TRAINING}

Psychotherapeutic procedure of autogenic training is regarded to be efficacious in the treatment of psychical disturbances, and it is an up-to-date method of treating depression and anxiety. Psychotherapeutic procedure of autogenic training is regarded to be efficacious in the treatment of psychical disturbances, and it is a modern method of treating depression and anxiety. Autogenic training is a child of hypnosis, but it is not its only source Its sister, whose mother is also hypnosis, is psychoanalysis. Their father is S. Freud, who introduced this therapy at the turn of the 19th and the 20th centuries. Psychoanalysis is based on the patient's 'opening up' and on the intensive 'discharging' of his feelings, and it is considered to be the queen of 
psychotherapy.Hypnosis is a very old treatment method and it was well known at the time of the old Egyptians, Greeks and Romans. The father of hypnosis is the famous British ophthalmologist, James Braid.Hypnotic phenomena initiate the development of psychoanalysis, and this is where autogenic training stems from. Its favourable effect not only heals and prevents illnesses, but it also facilitates an individual's gaining a better insight into their own role and place within the society, which leads to creation of a free personality, which becomes constructive in the realization of their rights and patient in the endurance of objective difficulties.

Autogenic training is a procedure aiming at achieving relaxation. It originated in the office of the psychotherapist J. H. Schultz, who used this method in order to treat ill people, but it gradually started to be practised with healthy population, in order to prevent diseases. There are two stages of these exercises: the basic stage and the advanced stage. The basic exercises consist of a series of exercises, by which, alongside with physical changes, by means of auto-suggestion, the person experiences a psychical relaxation as well. We might therefore say that autogenic training is autohypnosis rather than autosuggestion. It is a state which enables easier and more effective suggestive functioning. People doing autogenic training have a feeling they have everything in their hands, as they have become both the person being suggested to and the person suggesting. By means of autogenic training, the outer world is directed towards the inner world, which again enables the focus being directed towards one's own psychical life.

Autogenic training has to be gradually acquired. In the beginning, exercising for two minutes will suffice, but in the end, the exercises last for 20 minutes. It is recommended that people exercise three times a day. Autogenic training is a form of auto-analysis. It helps us get an insight into our physical changes and spiritual life through a series of associations, which were beyond our attention due to constant outer stimuli. Autogenic training is a silence which enables us to hear the weak 'voices' of our inner life.

The technique of autogenic training comprises the following:

[1] One should isolate from the surroundings - i.e. find a suitable place for the séance,

[2] close your eyes, in order to avoid the communication with the outer world,

[3] start with suggestion saying: PEACE, SERENE PEACE (once)

[4] what follows are the following suggestions: MY RIGHT (LEFT) ARM IS TOTALLY COMFORTABLY HEAVY (six times)

[5] PEACE, SERENE PEACE (once)

[6] MY RIGHT (LEFT) ARM IS TOTALLY COMFORTABLY HEAVY (six times)

[7] PEACE, SERENE PEACE (once)

[8] I AM BREATHING (six times)

[9] MY HEART IS BEATING PEACEFULLY AND RHYTHMICALLY (six times)

[10] PEACE, SERENE PEACE (once)

[11] MY STOMACH IS FILLED WITH PLEASANT WARMTH (six times)

[12] PEACE, SERENE PEACE (once)

[13] MY FOREHEAD IS PLEASANTLY COOL (six times)

[14] PEACE, SERENE PEACE (once).

Each formula is to be mastered within the period of two weeks, which means that autogenic training altogether lasts for three months. With the first two exercises, the person starts with either right or left hand, depending on whether the person is right-handed or left - handed. At the beginning and at the end of the exercise and in between the stages of the exercise one should suggest - serene peace. The contents that are suggested are to be mentally visualized by means of adequate symbolic images. The six formulae of autogenic training may be uttered in the period shorter than 20 minutes. After that, the person may either proceed to suggestions, the purpose of which is elimination of the symptoms, or stick to one and the same exercise, in order to feel it in full, experience it in the shadow of other accomplished suggestions (48).

\section{METHODS AND MATERIALS:}

This research was based on the treatment of psychogenic factors connected with stomatopyrosis as a symptom. The research was conducted on 1200 respondents suffering from stomatopyrosis, with an established psychical disorder. The respondents were divided into 4 groups. Each group contained 300 respondents whose main problem was a mental disorder with the presence of stomatopyrosis as an accompanying symptom. The first group comprised respondents treated by antidepressants. The group consisted of 230 women and 70 men (further in the paper, this group will be referred to as Antidepressants).The second group was composed of respondents treated with anxiolytics. It comprised 160 women and 140 men (further in the paper, this group will be referred to as Anxiolytics). 
The third group was treated by means of autogenic training. It contained 190 women and 110 men (further in the paper, this group will be referred to as Autogenic training).The control group contained 220 women and 80 men who were submitted to psychiatric treatment only (further in the paper, this group will be referred to as Control). The distribution of the respondents of both sexes is shown in Figure 1. The total number of women was $800(66.7 \%)$ and men $400(33.3 \%)$. The distribution of respondents suffering from stomatpyrosis most likely caused by psychogenic factors regarding their age and sex is as follows: they are mostly elderly people, between 50 and 70 , of both sexes. $11.3 \%$ of them are under 50 years, $22.5 \%$ of them are $51-55,15.8 \%$ of the respondents are between 56 and $60,13.3 \%$ between 61 and 65 , while $35.0 \%$ of the respondents are 66 and more. As each group consists of 300 respondents, each group makes $25 \%$ of the total.As far as their sex and age are concerned, the groups are statistically rather similar. The average age of 800 female respondents is 60.2 , ranging from 45 to 70 years, with a standard deviation of 7.08 years, while the average age of 400 male respondents was 60.7, ranging from 49 years to 72, with a standard deviation of 7.30. Each group is mainly predominated by respondents older than 65 years (ranging from 30\% to 43.3\%) The average age in the Antidepressants is 61.95 years, with a standard deviation of 6.27 years. The members of the Anxiolytics are on average 59.23 years old, with a standard deviation of 8.11 years. The average age of Autogenic training group was 60.17 years, with a standard deviation of 6.91 years and, finally, the average age of the Control group was 60.07 years, with a standard deviation of 7.17 years. The youngest members of the groups were from 45 to 51 years old, while the oldest ones were between 70 and 72 years.

Respondents were tested by means of interviews, and answers were inserted into the questionnaire. The questionnaire contained both general data and information required for the study of stomatopyrosis.Respondents were divided into 4 groups on the basis of diagnostic criteria. All four groups were treated by psychotherapy, i.e. psychotherapists were the people interviewing the respondents.Clinical part of the research was conducted in the Oral Diseases Clinic of the Stomatological faculty and in the Psychological medicine Clinic within Clinical Hospital Centre Zagreb. Psychological testing was conducted by psychologists. Respondents were under strict supervision of psychotherapists. Detailed clinical and psychological examinations preceded the implementation of the treatment method, and it followed later, after one month, after two months and after four months. The respondents are still undergoing the therapy. Psychotherapist supervises and estimates the treatment and decides on whether it will be continued or aborted, depending on the psychical condition of the respondents.

Subjective assessment of stomatopyrosis is difficult to evaluate scientifically. This is why this research defines the well known techniques which might be used to objectivize the symptoms of stomatopyrosis.Subjective assessment of the intensity of the burning sensation is obtained by means of the visual analogous scale, ranging from 0 to $10 \mathrm{~cm}$. 0 stands for the weakest sensation, while no. 10 represents the highest intensity. The respondents decide on their own the degree of the intensity of the burning sensation and mark the appropriate number on the visual measurement scale. Objective measurement is expressed in centimetres.

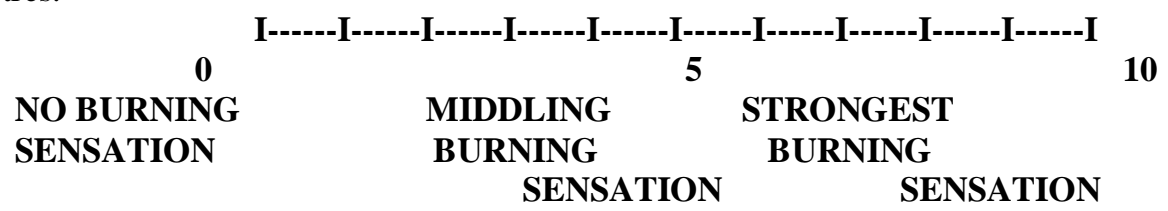

Two psychotests depicting respondents' specific psychological conditions were used. These tests are essential for the evaluation of the psychological condition of the respondents and for the follow-up during the treatment. The testing was conducted in such a way that the questionnaires were filled in by the respondents themselves before the beginning of the therapy, after one month, after two and, finally after four months after the beginning. As previous studies have confirmed, the most frequent psychological problems connected with the emerging of stomatopyrosis as a symptom are depression and anxiety. That is why we applied two questionnaires in our research:

[1] depression questionnaire, and

[2] anxiety questionnaire.

The first test to be applied was Depression questionnaire (Beck's test). It consists of 20 statements which depict the psychological condition of the respondent. The questions define the depression in terms such as: in a good mood, feeling like whining, peaceful and relaxed. Next to each statement, there are four answers offered, defining the frequency of respective phenomena with particular respondents, such as: 
[1] almost never,

[2] sometimes,

[3] frequently,

[4] almost always.

The second test was Anxiety questionnaire. It contains 20 questions which are to be answered with either YES or NO, and which describe the current condition of the patient suffering from the problem in question, such as: do you have headaches, do your hands shake, do you have sleeping problems, etc.

\section{RESULTS:}

Psychological tests objectivize psychological status of the respondents. Psychiatric diagnosis can be established, and so can the appropriate therapy, on the basis of psychological tests and by means of psychiatric interviews and the analysis of the respondents. Since our previous studies have proven that depression and anxiety are the most frequent findings with stomatopyrosis, we have applied two psychological tests in our research: anxiety test and depression test.The anxiety tests consists of 20 questions, answers to which are either YES or NO, and they refer to current psychical state of the respondents. The depression test contains 20 statements, each of which is followed by 4 answers related to the frequency of the occurrence of the specific phenomenon mentioned in the statement: almost never, occasionally, often, and always.

Table 1 shows the anxiety test in relation to gender and time intervals. At the beginning of the examination, the anxiety test is positive with $62.5 \%$ men and $32.5 \%$ women. After a one-month treatment, the anxiety test is positive with $37.5 \%$ men and $13.8 \%$ women.After the second month of therapy, the anxiety test shows primarily borderline and negative values. Positive anxiety findings are continually diminishing and now they are $7.5 \%$ with men and $8.8 \%$ with women. After four months of therapy, anxiety stopped decreasing. On the contrary, positive findings have increased to $10.0 \%$ with men. However, negative findings of anxiety tests have been constantly rising with both men and women.Figure 1 shows the relation of the groups according to time intervals as far as depression test is concerned. Patients suffering from stomatopyrosis who are treated with antidepressants show in the beginning a high percentage positive depression tests. After one month, the percentage starts dropping, while borderlines grow; after two months of therapy the depression tests show a high percentage of borderline values, and a few negative findings. In the 4th month there are only borderline and negative values, in equal percentages.

The second group of patients, the ones treated with anxiolytics, displayed at the beginning a high percentage of negative findings (as compared to depression tests), followed by borderline findings and, in a very small percentage, positive findings of depression. After a one-month therapy, and after second and fourth month, the percentage of negative findings has grown. The third group of patients shows in the beginning more positive findings in their depression tests, followed by borderline findings, and the depression test shows very few negative findings. After a month, positive values have dropped, while borderline and negative outcomes start growing. The second month is characterized by mainly borderline and negative depression test findings. In the fourth month, depression tests findings are, almost as a rule, negative. The control group has shown similar values in the beginning and after a month, while there was a slight fall in the positive findings after second and fourth months.

Tables $2 \mathrm{a}$ and $2 \mathrm{~b}$ show depression test according to time intervals and various groups. In the beginning, positive depression findings can be found with $96.7 \%$ of respondents from the first group; the second group has positive findings with only $3.3 \%$ of respondents, showing at the same time the highest negative depression values $(76.7 \%)$, followed by borderline findings $-20.0 \%$. The third group has positive depression test findings with $56.7 \%$ of respondents, and borderline findings are found with $40 \%$ of respondents. The control group has mainly borderline depression test values $-56.7 \%$. After a one-month therapy, the number of positive findings has dropped to $80 \%$, borderline values having risen from $3.3 \%$ to $20 \%$. In the second group, the borderline values have decreased to $16.7 \%$, negative findings having grown to $80 \%$. In the third group there is a fall in positive findings (to $43.7 \%$ ) and a rise in borderline values (to $46.7 \%$ ), while the negative findings have risen from $3.3 \%$ to $10 \%$ of respondents. The control group has 'kept' its borderline value at $56.7 \%$.After the second month of the treatment, the first group has significantly diminished positive percentage to $20 \%$ of the respondents, having increased the borderline values to $66.7 \%$ of the respondents; there are some negative values, too $-13.3 \%$. In the second group, there are no more respondents with positive depression test values; their findings are mostly negative $-93.3 \%$. The third group has decreased positive findings to $10.0 \%$, having increased borderline values to $56.7 \%$ and negative values to $33.3 \%$. The control group has shown a slight fall in positive findings $(13.3 \%)$, with borderline values present with $53.3 \%$ of the respondents and they slightly 
increased negative values to $33.3 \%$. After four months, the depression test shows primarily borderline values with 1 st group $-53.3 \%$, with no positive values, while negative values have risen to $46.7 \%$. The second group has increased negative values to $96.7 \%$ of the respondents, without positive values and with a minimum number of borderline values $-3.3 \%$. The third group has mainly shown negative (76.1\%) and borderline values (23.3\%), with no positive findings. The control group has approximately the same percentage of borderline and negative values (43.3\% of the respondents, each), without any change in positive values (13.3\%).The results of anxiety tests have been presented in graphical form in figure 2, in relation to time intervals and according to the groups. In the beginning, before the therapy, the first group showed negative anxiety values, with some borderline and very few positive findings. After a one-month therapy, negative values have risen, while borderline values of the anxiety test have remained the same. After two months of the therapy, negative values of anxiety test have increased, the same happening after the period of 4 months.

The second group has shown in the beginning a high percentage of positive and borderline anxiety test values. After a one-month therapy, the anxiety test has shown similar percentage of positive and borderline values and very few negative findings. During the second month, negative and borderline anxiety test values are equal, while after the fourth month the anxiety test values are mainly negative. The third group showed at the beginning a high percentage of positive anxiety test values and some borderline and negative findings. During the therapy the borderline values significantly rose; after 2 months, borderline and negative values were similar, and after four months, the majority of the respondents showed a high percentage of negative findings with some borderline findings.At the very beginning, the control group had a similar percentage of negative, positive and borderline anxiety test values. After one month, negative findings rose and the positive ones fell. After two months, negative values were even higher, the same happening after 4 months.Tables $3 \mathrm{a}$ and $3 \mathrm{~b}$ show numerical relation of the anxiety test results according to the groups of respondents and the time intervals. At the very beginning, the first group showed mainly negative anxiety test values (80\%), with some borderline values (16.7\%) and minimal negative values (3.7\%). The second group had primarily positive anxiety test values (90\%) and only $10 \%$ of borderline findings, with none of the respondents with negative values. The third group had at the beginning positive findings with 53.3\% of the respondents, borderline values with $30 \%$ and negative with $10 \%$. The control group had the highest number of borderline values $-43.3 \%$, followed by $23.3 \%$ positive and $33.3 \%$ negative findings. After a one-month therapy, the first group increased the number of negative findings to $86.7 \%$, with $13.3 \%$ of borderline values, and no positive findings.

The second group has significantly decreased positive values - the percentage has dropped to $43.3 \%$ of the respondents and borderline values have increased to $53.3 \%$, with negative findings with $3.7 \%$ of the respondents. The third group had mostly borderline values $-60 \%$, while positive findings have dropped to $23.3 \%$ of the respondents, with negative ones having grown to $16.3 \%$ of the respondents. The fourth group showed a slight decrease in the positive values (to $20 \%$ of the respondents), while $40 \%$ them had borderline values and the negative findings having grown to $40 \%$. After two months of treatment, the anxiety test is in the first group mostly negative $-90 \%$, with only $6.7 \%$ of borderline and $3.3 \%$ positive findings. The second group has the same number of borderline and negative findings $-43.3 \%$ and only $13.3 \%$ of positive values. The third group has showed borderline and negative findings with $50 \%$ of the respondents and no positive findings whatsoever. The control group has negative findings with $50 \%$ of the respondents, $33.3 \%$ borderline and $16.7 \%$ of the positive values. After four months of therapy, there was an improvement in all four groups and the anxiety test values were mostly negative: in the first group $90 \%$, in the second group $73.3 \%$, in the third group $83.3 \%$, and in the fourth group 56.7\%. The results of the analysis of psychological tests in relation to the time intervals according to the groups of respondents show a statistical significance; i.e. the anxiety test has shown that the therapy brought improvement in the psychical state of the respondents, in all cases but the fourth group, whose mental state has improved at slower rates.

\section{CONCLUSION:}

Antidepressants and anxiolytics have a prominent place in the therapy of stomatopyrosis. Psychological tests conducted after 4 months have proven the improvement - anxiety dropped to $7.5 \%-8.8 \%$, while depression completely disappeared in some of the tested groups. At the same time, the subjective assessment of the symptom intensity on VAS scale dropped from $6.93-7.8$ to $2.13-3.0 \mathrm{~cm}$. At the beginning of the treatment, the symptoms were often present with $36.7 \%-76.7 \%$ of the respondents, and continually with $23.3 \%$ $-63.3 \%$ of the respondents. At the end of the treatment majority of respondents reported that the frequency of the stomatopyrosis symptoms was very rarely.Autogenic training - psychotherapeutical anxiolytical technique is the therapy of choice for stomatopyrosis, both in elimination of the problems in the oral cavity and in the emotional rehabilitation of the patients. 


\section{ACKNOWLEDGEMENTS: None CONFLICT OF INTEREST: None to declare}

\section{REFERENCES:}

[1.] Feiman CH, Harris M, Cawlay R. Psychological facial pain. Presentation and treatment. Br Med J 1984; $288: 436-438$. Hammeren M, Hudoson A.Clinic psychiatric assessment of patient with burning mouth syndrome resisting oral treatment. Swed Dent J 1989; 13:77-88.

[2.] Domb GH, Chole Ra. The burning mouth and tongue. Ear Throat J 1981; 60:310-4

[3.] Hamf G, Vikkula J, Ylipaavaluien P, Adlgert V. Psychiatric disorders in orofacial dysesthesia. Int J Oral Max Surg 1987; 16:402-7.

[4.] Lamey PJ, Lamb AB.The usefulness of HAD scale in assessing anxiety and depression in patients with burning mouth syndrome. Oral Surg, Oral Med, Oral Pathol 1989; 67:390-2.

[5.] Nesbitt WR, Brody HA.Psychosomatic oral problems. Journal Med 1967;22:43-6.

[6.] Browing S, Hislop S, Scully C, Shirlaw P.The association between burning mouth syndrome and psychosocial disorders. Oral Surg, Oral Med, Oral Pathol 1987; 64:171-4.

[7.] Gruden-Pokupec JS, Arambašin-Cekić A, Gruden V.(2000) Psihološka testiranja kod sindroma pečenja usta. Coll Antrop 2000;1:119-126.

[8.] Lamey PJ, Lamb AB.Etiological factors in burning mouth syndrome. A prospective study. Br Med J 1988; $296: 1243-6$.

[9.] Van der Ploeg, Van der Wall N, Eijkman MAJ, Van der Wall I. Psychological aspect in patients with burning mouth syndrome. Oral Surg, Oral Med, Oral Pathol 1987;63:664-8.

[10.] Schoenberg B, Carr Ac, Kutscer AH, Zegarelli EV.Chronic idiopathic orolingual pain. Psychogenetics of burning mouth. NY State J Med1971; 71:1832-7.

[11.] Basket RM, Strudee DW, Daverport JC.Patients with burning mouth. Clinical investigators of causative factors including of climacteric and diabetes. Br Dent J 1987; 145:9-16.

[12.] Rojo L, Silvestre FJ, Bagan JV, De Vicence T.Psychiatric mobility in burning mouth syndrome. Psychiatric interview versus depression and anxiety scales. Oral Surg, Oral Med, Oral Pathol 1993;75:308-11.

[13.] Jerlang BB.Burning mouth syndrome BMS and concept of alexithymia preliminary study. J Oral Pathol Med.1997; 26:249-53.

[14.] Coles RB.Glossodynia - A psychosomatic oral problems. J Oral Med.1967 2243-6.

[15.] Greenberg JR, Mitchell SA.Object relations in psychoanalytic theory. Cambridge; Harvard University 1983.

[16.] Greenberg RP Bornstein RF Greenberg MD Ficher S.A meta-analysis of antidepressant outcome under "blinder" conditions. J of Consul and Clin Psyho1992;.60:664-9.

[17.] Ficher S, Greenberg RP.How sounds is the double-blind design for evaluating psychotropic drugs? The J of Nerv and Ment Desease.1993;181:345-50

[18.] Botha PA.Burning mouth syndrome and psychotherapy. Psychology Department, University of Pretoria, Pretoria, South Africa. Dissertation2000

[19.] Klein M. Infantile anxiety situations reflected in a work of art and in the creative impulse.The selected Melanie Klein London1991; 84-94.

[20.] Klein M. The psycho-analytic play technique. Its history and significance. The selected Melanie Klein London 1991; 35-55.

[21.] Cashdan S.Objective relations therapy: using the relationships. NY:WWNortan and company 1988.

[22.] Blatt S, Ford RQ. Therapeutic change: An object relations perspective. London Plenum.1994.

[23.] Spillius EB. Clinical experiences of projective identification. In R Anderson (Ed), Clinical Lectures on Bion and Klien London. 1995;59-73.

[24.] Malan DH, Osimo F. Psychodynamic training and outcome in brief psychotherapy. Oxford: Butterworth-Heinemann Ltd.2003

[25.] Grushka M.Clonazepam Offers Hope For Relief From Mouth Pain. Amer Dent Assoc 1998.

[26.] Eli I, Bath R, Litter MM, Kleinhauz M. Detection of psychopathological traits in glossodynia patients. Psyhosom Med.1999; 56:389-394

[27.] Eli I, Kleinhauz M, Bath R, Littner M.Antecedents of burning mouth syndrome (glossodynia). Recent life events vs psychopathological aspects. J Dent Res.1994;73:567-572.

[28.] Van Houdenhove, Vasques G, Neerinckx GE.Tender points or tender patients? The value of the psychiatric in-depth interview for assessing and understanding psychopathological aspects for fibrimyalgia. ClinRheum.1994;13:470-474.

[29.] Van Houdenhove, B Joostens P.Burning mouth syndrome. Successful Treatment with Combined Psychotherapy and Psychofarmacotherapy. Gener Hosp Psyh.1995;17:385-8.

[30.] Grohol JM.Psychotherapy for depression. Your first and best treatment choice. J Amer Psyh:1995; 50:6-8.

[31.] Antonuccio DO.Psychotherapy for depression. No stronger medicine. J Amer Psyho.1996;50:450-2.

[32.] Antonuccio DO Danton WG DeNelsky GY. Psychotherapy for depression. No stronger medicine. J Scien Prac.1994;4(1):2-18.

[33.] Wexler BE, Cicchetti DV.The outpatients treatment of depression. Implication of outcome research for clinic practice. The J of Nerv and Ment Desease.1992;180(5):277-286.

[34.] Karon BP, Teixeira MA. Guidelines for the treatment of depression in primary care and the APA response. Amer Psyho.1996;50:453-5

[35.] Bergdahl J, Anneroth G, Perris H.Cognate therapy in the treatment of patients with resistant burning mouth syndrome. A controlled study. J Oral Med1995; 24:312-5

[36.] Dobrenić M, Cekić-Arambašin A, Vidas I.Rizični čimbenici i mogućnost njihove eliminacije kod stomatopiroze. (Risk factors and the possibility of their elimination with stomatopyrosis). Acta Stom Croa1984; 18:217-21.

[37.] Nater JP, Groeman NH, Wankerns-Garrisen BG, Timmer LH.Etiological factors in denture sore mouth syndrome. J Prosth.Dent 1978; 40:367-73.

[38.] Kaltz J, Beniliel R, Leviner E.Burning mouth sensation associated with fusospirochetal infection in edembulous patients. Oral Surg, Oral Med, Oral Pathol 1986; 62:152-4.

[39.] Maresky LS, Van Der Bijl P, Girl I.Burning mouth syndrome. Evaluation of multiple variables among 85 patients. Oral Surg, Oral Pathol Oral Med1993; 75:303-6.

[40.] James J, Ferguson MM, Forsyth A.Mercury allergy as cause of burning mouth, Br Dent J 1985;159:392.

[41.] Kabeer S, Thulin H, Nielsen E. Skin sensitivity to denture base materials in burning mouth. Cont Derm 1979; 5:90-6.

[42.] Thomson JC.The load factor in complain denture intolerance. J Prosthel Dent 1971;15:4-11. 
Anxiolytics, Antidepressants And Autogenous...

[43.] Epstein. International Association for the study of pain. Subcommunite on Taxonomy. Classification of chronic pain and definitions of pain terms. Pain 1986;3:368

[44.] Glass BJ, Vis Dis ML, Launglais RP, Miles DA.Xerostomia: diagnosis and treatment planning considerations. Oral Surg, Oral Med, Oral Pathol 1984;58:248-52.

[45.] Feldman M.Splitting and projective identification. In R Anderson (Ed), Clinical rectors Bion and Klein London. 1995;74-88.

[46.] Vrhovac B. Klinička farmakologija. (Clinical pharmacology) Jumena, IV izdanje.1990.

TABLE 1: Distribution of the results of the Anxiety test taken at different times and the results of the corresponding

\begin{tabular}{|c|c|c|c|c|c|c|c|c|c|}
\hline \multirow{2}{*}{$\begin{array}{l}\text { Time of } \\
\text { testing }\end{array}$} & \multirow[t]{2}{*}{ Gender } & \multicolumn{3}{|c|}{ Anxiety test } & \multirow{2}{*}{$\begin{array}{l}\square^{2} \text { - test } \\
\text { Negative }\end{array}$} & \multirow[b]{2}{*}{ Total } & \multirow[b]{2}{*}{$\square^{2}$} & \multirow[b]{2}{*}{ dff } & \multirow[b]{2}{*}{$\mathbf{P}$} \\
\hline & & & Positive & Borderline & & & & & \\
\hline \multirow{3}{*}{$\begin{array}{l}\text { At the } \\
\text { beginning }\end{array}$} & Female & $\begin{array}{l}\mathbf{n} \\
\mathbf{h p}\end{array}$ & $\begin{array}{l}260 \\
32.5 \%\end{array}$ & $\begin{array}{l}260 \\
32.5 \%\end{array}$ & $\begin{array}{l}280 \\
35.0 \%\end{array}$ & $\begin{array}{l}800 \\
100.0 \%\end{array}$ & \multirow{3}{*}{10.061} & \multirow{3}{*}{2} & \multirow{3}{*}{0.007} \\
\hline & Male & $\begin{array}{l}\text { n } \\
\mathbf{h}_{\mathbf{p}}\end{array}$ & $\begin{array}{l}250 \\
62.5 \%\end{array}$ & $\begin{array}{l}60 \\
15.0 \%\end{array}$ & $\begin{array}{l}90 \\
22.5 \%\end{array}$ & $\begin{array}{l}400 \\
100.0 \%\end{array}$ & & & \\
\hline & Total & $\begin{array}{l}\mathbf{n} \\
\mathbf{h}_{\mathbf{p}}\end{array}$ & $\begin{array}{l}510 \\
42.5 \% \\
\end{array}$ & $\begin{array}{l}320 \\
26.7 \%\end{array}$ & $\begin{array}{l}370 \\
30.8 \%\end{array}$ & $\begin{array}{l}1200 \\
100.0 \%\end{array}$ & & & \\
\hline \multirow{3}{*}{$\begin{array}{l}\text { After 1 } \\
\text { month }\end{array}$} & Female & $\begin{array}{l}\mathbf{n} \\
h_{p}\end{array}$ & $\begin{array}{l}110 \\
13.8 \%\end{array}$ & $\begin{array}{l}350 \\
43.8 \%\end{array}$ & $\begin{array}{l}340 \\
42.5 \%\end{array}$ & $\begin{array}{l}800 \\
100.0 \%\end{array}$ & \multirow{3}{*}{9.420} & \multirow{3}{*}{2} & \multirow{3}{*}{0.009} \\
\hline & Male & $\begin{array}{l}\mathbf{n} \\
h_{p}\end{array}$ & $\begin{array}{l}150 \\
37.5 \%\end{array}$ & $\begin{array}{l}150 \\
37.5 \%\end{array}$ & $\begin{array}{l}100 \\
25.0 \%\end{array}$ & $\begin{array}{l}400 \\
100.0 \%\end{array}$ & & & \\
\hline & Total & $\begin{array}{l}\mathbf{n} \\
\mathbf{h p}\end{array}$ & $\begin{array}{l}260 \\
21.7 \%\end{array}$ & $\begin{array}{l}500 \\
41.7 \%\end{array}$ & $\begin{array}{l}440 \\
36.7 \%\end{array}$ & $\begin{array}{l}120 \\
100.0 \%\end{array}$ & & & \\
\hline \multirow{3}{*}{$\begin{array}{l}\text { After 2 } \\
\text { months }\end{array}$} & Female & $\begin{array}{l}\mathbf{n} \\
\text { hp }\end{array}$ & $\begin{array}{l}70 \\
8.8 \%\end{array}$ & $\begin{array}{l}190 \\
23.8 \%\end{array}$ & $\begin{array}{l}540 \\
67.5 \%\end{array}$ & $\begin{array}{l}800 \\
100.0 \%\end{array}$ & \multirow{3}{*}{10.12} & \multirow{3}{*}{2} & \multirow{3}{*}{0.006} \\
\hline & Male & $\begin{array}{l}\text { n } \\
\mathbf{h}_{\mathbf{p}}\end{array}$ & $\begin{array}{l}30 \\
7.5 \%\end{array}$ & $\begin{array}{l}210 \\
52.5 \%\end{array}$ & $\begin{array}{l}160 \\
40.0 \%\end{array}$ & $\begin{array}{l}400 \\
100.0 \%\end{array}$ & & & \\
\hline & Total & $\begin{array}{l}\mathbf{n} \\
\mathbf{h}_{\mathbf{p}}\end{array}$ & $\begin{array}{l}100 \\
8.3 \%\end{array}$ & $\begin{array}{l}400 \\
33.3 \%\end{array}$ & $\begin{array}{l}700 \\
58.3 \%\end{array}$ & $\begin{array}{l}1200 \\
100.0 \%\end{array}$ & & & \\
\hline \multirow{3}{*}{$\begin{array}{l}\text { After } 4 \\
\text { months }\end{array}$} & Female & $\begin{array}{l}\mathbf{n} \\
\mathbf{h}_{\mathbf{p}}\end{array}$ & $\begin{array}{l}70 \\
8.8 \% \\
\end{array}$ & $\begin{array}{l}100 \\
12.5 \%\end{array}$ & $\begin{array}{l}630 \\
78.8 \% \\
\end{array}$ & $\begin{array}{l}800 \\
100.0 \%\end{array}$ & \multirow{3}{*}{1.315} & \multirow{3}{*}{2} & \multirow{3}{*}{0.518} \\
\hline & Male & $\begin{array}{l}\text { n } \\
\text { hp }\end{array}$ & $\begin{array}{l}40 \\
10.0 \%\end{array}$ & $\begin{array}{l}80 \\
20.0 \%\end{array}$ & $\begin{array}{l}280 \\
70.0 \%\end{array}$ & $\begin{array}{l}400 \\
100.0 \%\end{array}$ & & & \\
\hline & Total & $\begin{array}{l}\text { n } \\
\text { hp }\end{array}$ & $\begin{array}{l}110 \\
9.2 \%\end{array}$ & $\begin{array}{l}180 \\
15.0 \%\end{array}$ & $\begin{array}{l}910 \\
75.8 \%\end{array}$ & $\begin{array}{l}1200 \\
100.0 \%\end{array}$ & & & \\
\hline
\end{tabular}

Legend:n - the number of cases hp - horizontal percentage

FIGURE 1: Distribution of the results of Depression test according to the groups of respondents taken at different times $(\mathrm{N}=120)$
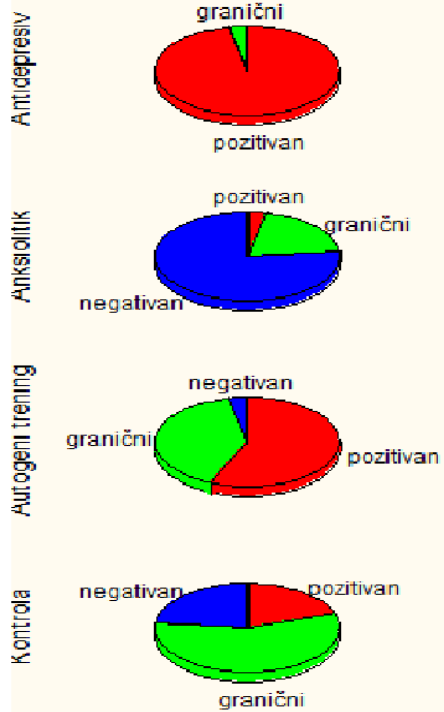

Početak
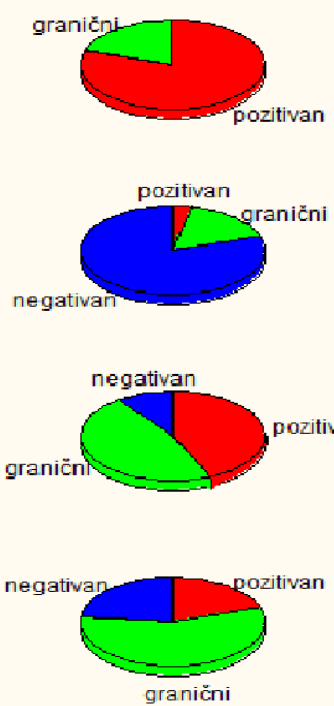

1 mjesec
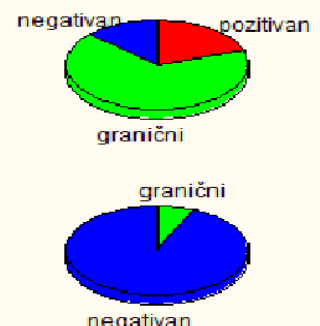

negativan
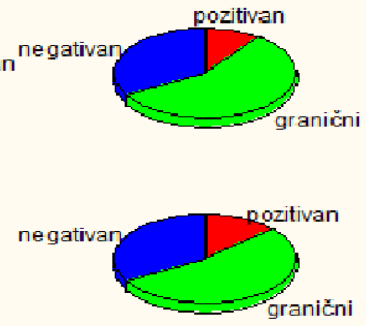

2 mjeseca
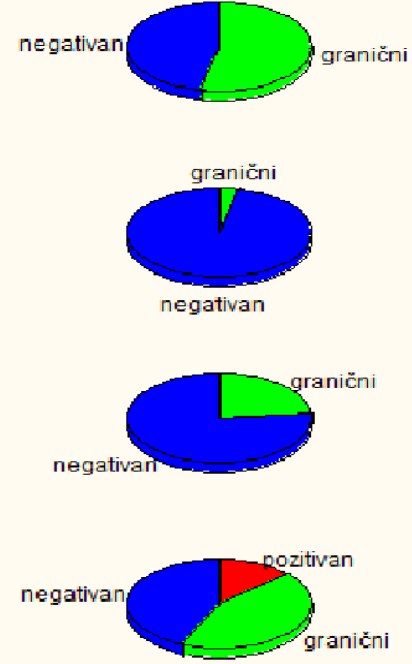

4 mjeseca

\section{LEGEND (translation):}

Granični - borderline

Pozitivan - positive

Negativan - negative

Antidepresiv - antidepressants 
Anksiolitik - anxiolytics

Autogeni trening - autogenic training

Kontrola - control

Početak - beginning

1 mjesec - 1 month

2 mjeseca -2 months

4 mjeseca -4 months

TABLE 2a: Distribution of the results of Depression tests according to the groups of respondents taken at different times and the results of the corresponding $\square^{2}$ - tests

\begin{tabular}{|c|c|c|c|c|c|c|c|c|c|}
\hline \multirow{2}{*}{$\begin{array}{l}\text { Time of } \\
\text { testing }\end{array}$} & \multirow[t]{2}{*}{ Group } & & \multicolumn{2}{|c|}{ Depression test } & \multirow[b]{2}{*}{ Negative } & \multirow[b]{2}{*}{ Total } & \multirow[b]{2}{*}{$\overline{\square^{2}}$} & \multirow[b]{2}{*}{ df } & \multirow[b]{2}{*}{$P$} \\
\hline & & & Positive & Borderline & & & & & \\
\hline \multirow{5}{*}{$\begin{array}{l}\text { At the } \\
\text { beginning }\end{array}$} & Antidepressants & $\begin{array}{l}\mathrm{n} \\
\mathrm{hp}\end{array}$ & $\begin{array}{l}290 \\
96.7 \%\end{array}$ & \begin{tabular}{|l|}
10 \\
$3.3 \%$ \\
\end{tabular} & & \begin{tabular}{|l|}
300 \\
$100.0 \%$
\end{tabular} & \multirow{5}{*}{95.007} & \multirow{5}{*}{6} & \multirow{5}{*}{$<0.001$} \\
\hline & Anxiolytics & $\begin{array}{l}\mathrm{n} \\
\mathrm{hp} \\
\end{array}$ & $\begin{array}{l}10 \\
3.3 \% \\
\end{array}$ & \begin{tabular}{|l|}
60 \\
$20.0 \%$ \\
\end{tabular} & $\begin{array}{l}230 \\
76.7 \% \\
\end{array}$ & \begin{tabular}{|l|}
300 \\
$100.0 \%$ \\
\end{tabular} & & & \\
\hline & Autogenic training & $\begin{array}{l}\mathrm{n} \\
\mathrm{hp} \\
\end{array}$ & \begin{tabular}{|l|l}
170 \\
$\mathbf{5 6 . 7} \%$ \\
\end{tabular} & \begin{tabular}{|l|}
120 \\
$40.0 \%$ \\
\end{tabular} & $\begin{array}{l}10 \\
3.3 \% \\
\end{array}$ & \begin{tabular}{|l|}
300 \\
$100.0 \%$ \\
\end{tabular} & & & \\
\hline & Control & $\begin{array}{l}\mathrm{n} \\
\mathrm{hp}\end{array}$ & $\begin{array}{l}60 \\
20.0 \% \\
\end{array}$ & \begin{tabular}{|l|}
170 \\
$56.7 \%$ \\
\end{tabular} & $\begin{array}{l}70 \\
23.3 \% \\
\end{array}$ & $\begin{array}{l}300 \\
100.0 \% \\
\end{array}$ & & & \\
\hline & Total & $\begin{array}{l}\mathrm{n} \\
\mathrm{hp}\end{array}$ & $\begin{array}{l}530 \\
44.2 \%\end{array}$ & \begin{tabular}{|l|}
360 \\
$30.0 \%$
\end{tabular} & $\begin{array}{l}310 \\
25.8 \%\end{array}$ & $\begin{array}{l}1200 \\
100.0 \%\end{array}$ & & & \\
\hline \multirow{5}{*}{$\begin{array}{l}\text { After } 1 \\
\text { month }\end{array}$} & Antidepressants & $\begin{array}{l}\mathrm{n} \\
\mathrm{hp}\end{array}$ & $\begin{array}{l}240 \\
80.0 \%\end{array}$ & $\begin{array}{l}60 \\
20.0 \%\end{array}$ & & $\begin{array}{l}300 \\
100.0 \%\end{array}$ & \multirow{5}{*}{77.679} & \multirow{5}{*}{9} & \multirow{5}{*}{$<0.001$} \\
\hline & Anxiolytics & $\begin{array}{l}\mathrm{n} \\
\mathrm{hp}\end{array}$ & $\begin{array}{l}10 \\
3.3 \% \\
\end{array}$ & \begin{tabular}{|l|}
50 \\
$16.7 \%$ \\
\end{tabular} & $\begin{array}{l}240 \\
80.0 \% \\
\end{array}$ & \begin{tabular}{|l|}
300 \\
$100.0 \%$ \\
\end{tabular} & & & \\
\hline & Autogenic training & $\begin{array}{l}\text { n } \\
\text { hp }\end{array}$ & $\begin{array}{l}130 \\
43.3 \% \\
\end{array}$ & \begin{tabular}{|l|}
140 \\
$46.7 \%$ \\
\end{tabular} & $\begin{array}{l}30 \\
10.0 \%\end{array}$ & \begin{tabular}{|l|}
300 \\
$100.0 \%$ \\
\end{tabular} & & & \\
\hline & Control & $\begin{array}{l}\mathrm{n} \\
\mathrm{hp} \\
\end{array}$ & $\begin{array}{l}60 \\
20.0 \% \\
\end{array}$ & \begin{tabular}{|l|}
170 \\
$\mathbf{5 6 . 7 \%}$ \\
\end{tabular} & $\begin{array}{l}70 \\
23.3 \% \\
\end{array}$ & \begin{tabular}{|l|}
300 \\
$100.0 \%$ \\
\end{tabular} & & & \\
\hline & Total & $\begin{array}{l}\mathrm{n} \\
\mathrm{hp}\end{array}$ & $\begin{array}{l}440 \\
36.7 \%\end{array}$ & $\begin{array}{l}420 \\
35.0 \%\end{array}$ & $\begin{array}{l}340 \\
28.3 \%\end{array}$ & $\begin{array}{l}1200 \\
100.0 \%\end{array}$ & & & \\
\hline
\end{tabular}

Legend:n - number of cases hp - horizontal percentage

TABLE 2b : Distribution of the results of Depression test according to the groups of respondents taken at different times and the results of the corresponding $\square^{2}$-tests

\begin{tabular}{|c|c|c|c|c|c|c|c|c|c|}
\hline \multirow[t]{2}{*}{$\begin{array}{ll}\text { Time } & \text { of } \\
\text { testing } & \end{array}$} & \multirow[t]{2}{*}{ Group } & & \multirow{2}{*}{$\begin{array}{l}\text { Depression } \\
\text { test } \\
\text { Positive }\end{array}$} & \multirow{2}{*}{$\begin{array}{l}\square^{2} \text { - test } \\
\text { Borderline }\end{array}$} & & & & & \\
\hline & & & & & Negative & Total & $\square^{2}$ & df & $P$ \\
\hline \multirow{5}{*}{$\begin{array}{l}\text { After 2 } \\
\text { months }\end{array}$} & Antidepressants & $\begin{array}{l}\mathrm{n} \\
\mathrm{hp}\end{array}$ & $\begin{array}{l}60 \\
20.0 \%\end{array}$ & $\begin{array}{l}200 \\
66.7 \%\end{array}$ & $\begin{array}{l}40 \\
13.3 \%\end{array}$ & $\begin{array}{l}300 \\
100.0 \%\end{array}$ & \multirow{5}{*}{44.710} & \multirow{5}{*}{$\mid 6$} & \multirow{5}{*}{$<0.001$} \\
\hline & Anxiolytics & $\begin{array}{l}\text { n } \\
\text { hp }\end{array}$ & & $\begin{array}{l}20 \\
6.7 \%\end{array}$ & \begin{tabular}{|l|}
280 \\
$93.3 \%$
\end{tabular} & $\begin{array}{l}300 \\
100.0 \%\end{array}$ & & & \\
\hline & Autogenic training & $\begin{array}{l}\text { n } \\
\text { hp }\end{array}$ & $\begin{array}{l}30 \\
10.0 \% \\
\end{array}$ & $\begin{array}{l}\mathbf{1 7 0} \\
\mathbf{5 6 . 7} \% \\
\end{array}$ & \begin{tabular}{|l|}
100 \\
$33.3 \%$ \\
\end{tabular} & \begin{tabular}{|l|}
300 \\
$100.0 \%$ \\
\end{tabular} & & & \\
\hline & Control & $\begin{array}{l}\text { n } \\
\text { hp }\end{array}$ & $\begin{array}{l}40 \\
13.3 \%\end{array}$ & $\begin{array}{l}160 \\
\mathbf{5 3 . 3} \%\end{array}$ & $\begin{array}{l}100 \\
33.3 \%\end{array}$ & $\begin{array}{l}300 \\
100.0 \%\end{array}$ & & & \\
\hline & Total & $\begin{array}{l}\mathrm{n} \\
\text { hp }\end{array}$ & $\begin{array}{l}130 \\
10.8 \%\end{array}$ & $\begin{array}{l}550 \\
45.8 \%\end{array}$ & \begin{tabular}{|l|}
520 \\
$43.3 \%$ \\
\end{tabular} & $\begin{array}{l}1200 \\
100.0 \%\end{array}$ & & & \\
\hline \multirow{5}{*}{$\begin{array}{l}\text { After } 4 \\
\text { months }\end{array}$} & Antidepressants & $\begin{array}{l}\mathrm{n} \\
\mathrm{hp}\end{array}$ & & $\begin{array}{l}160 \\
53.3 \%\end{array}$ & \begin{tabular}{|l|l|}
140 \\
$46.7 \%$ \\
\end{tabular} & $\begin{array}{l}300 \\
100.0 \% \\
\end{array}$ & \multirow{5}{*}{35.199} & \multirow{5}{*}{6} & \multirow{5}{*}{$<0.001$} \\
\hline & Anxiolytics & $\begin{array}{l}\text { n } \\
\text { hp }\end{array}$ & & $\begin{array}{l}10 \\
3.3 \%\end{array}$ & \begin{tabular}{|l|}
290 \\
$96.7 \%$
\end{tabular} & $\begin{array}{l}300 \\
100.0 \%\end{array}$ & & & \\
\hline & Autogenic training & $\begin{array}{l}\text { n } \\
\text { hp }\end{array}$ & & $\begin{array}{l}70 \\
23.3 \%\end{array}$ & \begin{tabular}{|l|}
230 \\
$76.7 \%$
\end{tabular} & $\begin{array}{l}300 \\
100.0 \% \\
\end{array}$ & & & \\
\hline & Control & $\begin{array}{l}\text { n } \\
\text { hp }\end{array}$ & $\begin{array}{l}40 \\
13.3 \% \\
\end{array}$ & $\begin{array}{l}130 \\
43.3 \% \\
\end{array}$ & \begin{tabular}{|l|}
130 \\
$43.3 \%$ \\
\end{tabular} & \begin{tabular}{|l|}
300 \\
$100.0 \%$ \\
\end{tabular} & & & \\
\hline & Total & $\begin{array}{l}\mathrm{n} \\
\mathrm{ho} \\
\end{array}$ & $\begin{array}{l}40 \\
3.3 \% \\
\end{array}$ & $\begin{array}{l}370 \\
30.8 \% \\
\end{array}$ & $\begin{array}{l}790 \\
65.8 \% \\
\end{array}$ & $\begin{array}{l}1200 \\
100.0 \%\end{array}$ & & & \\
\hline
\end{tabular}


Legend:n - number of cases hp - horizontal percentage

FIGURE 2: Distribution of anxiety test results according to the groups of respondents and different testing times $(\mathrm{N}=\mathbf{1 2 0})$
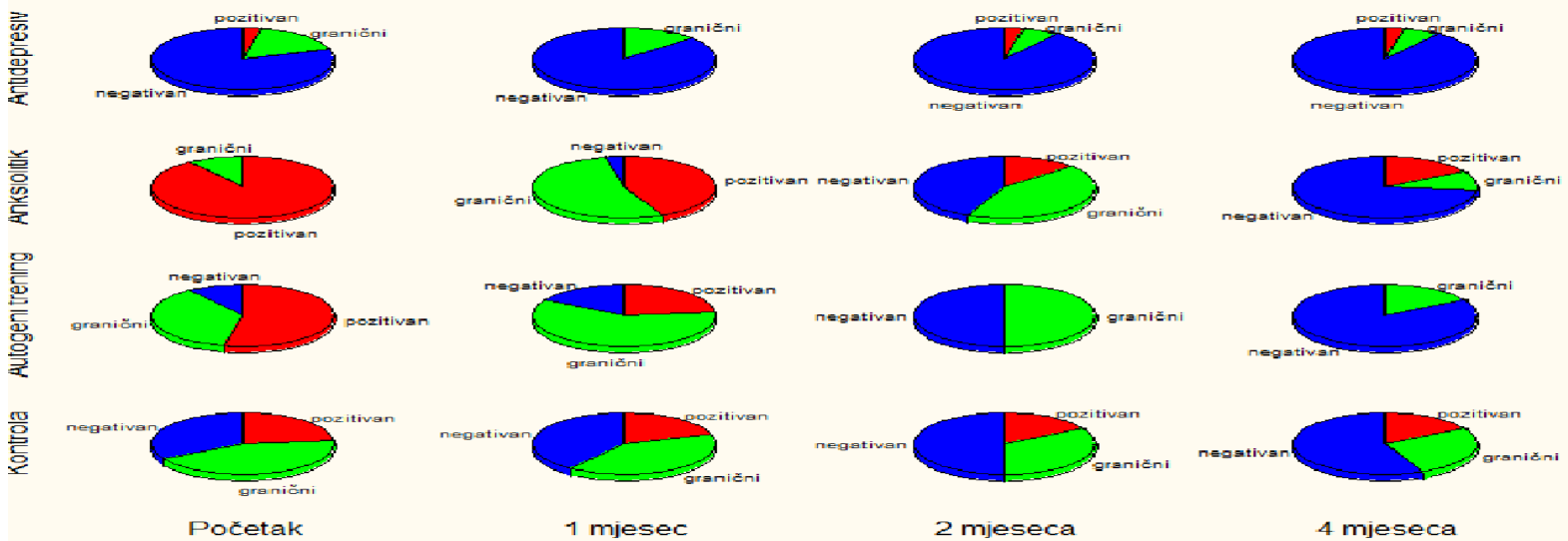

LEGEND (translation):

Granični - borderline

Pozitivan - positive

Negativan - negative

Antidepresiv - antidepressants

Anksiolitik - anxiolytics

Autogeni trening - autogenic training

Kontrola - control

Početak - beginning

1 mjesec - 1 month

2 mjeseca -2 months

4 mjeseca -4 months

TABLE 3a : Distribution of the results of the Anxiety test according to the groups of respondents at different times of testing and the results of the corresponding $\square^{2}$-tests.

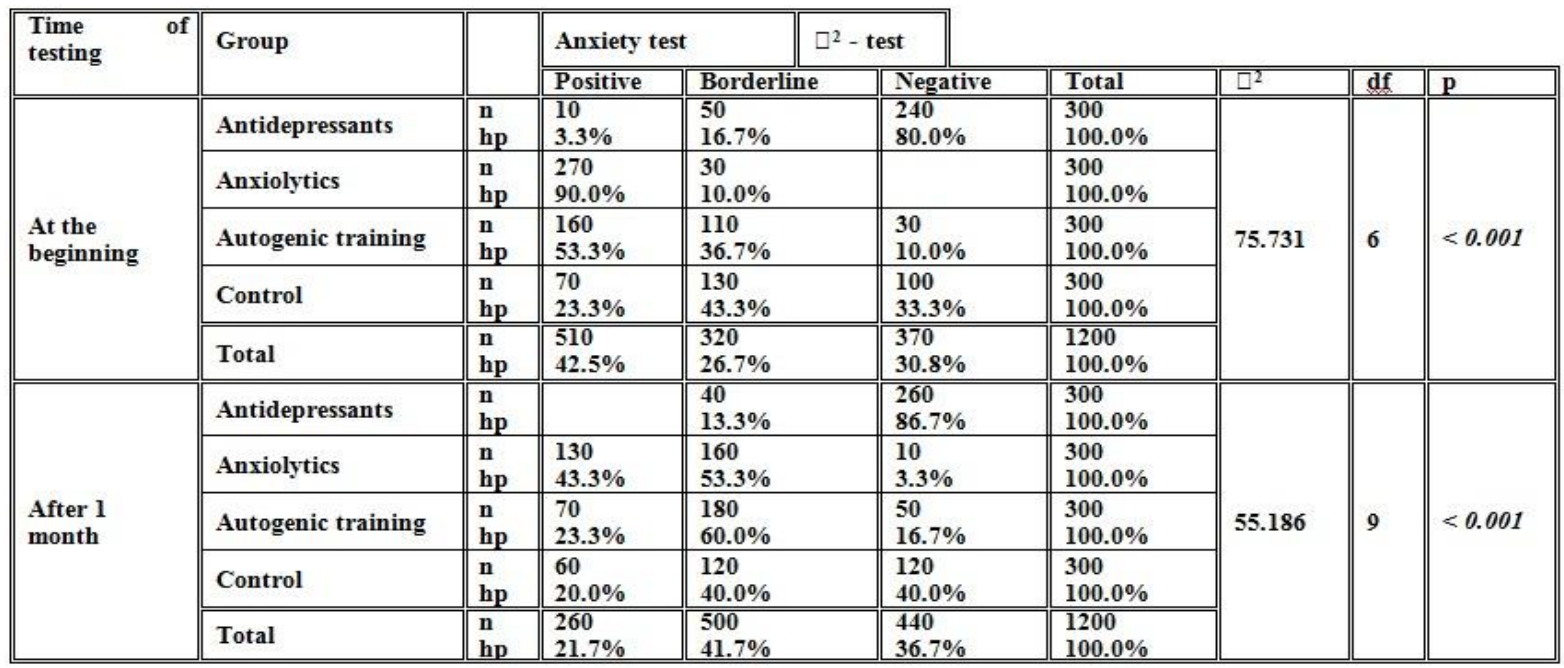

Legend:n - number of cases hp - horizontal percentage

TABLE 3b: Distribution of the results of the Anxiety test according to the groups of respondents taken at different times and the results of the corresponding $\square^{2}$-tests. 


\begin{tabular}{|c|c|c|c|c|c|c|c|c|c|}
\hline \multirow{2}{*}{$\begin{array}{ll}\text { Time } & \text { of } \\
\text { testing } & \end{array}$} & \multirow[t]{2}{*}{ Group } & & \multirow{2}{*}{\begin{tabular}{||l} 
Anxiety test \\
Positive \\
\end{tabular}} & $\square^{2}$ - test & \multirow[b]{2}{*}{ Negative } & \multirow[b]{2}{*}{ Total } & \multirow[b]{2}{*}{$\square^{2}$} & \multirow[b]{2}{*}{ df } & \multirow[b]{2}{*}{$\mathrm{P}$} \\
\hline & & & & Borderline & & & & & \\
\hline \multirow{5}{*}{$\begin{array}{l}\text { After } 2 \\
\text { months }\end{array}$} & Antidepressants & \begin{tabular}{|l}
$n$ \\
$h p$
\end{tabular} & \begin{tabular}{|l|l}
10 \\
$3.3 \%$ \\
\end{tabular} & \begin{tabular}{|l|l}
20 \\
$6.7 \%$
\end{tabular} & $\begin{array}{l}270 \\
90.0 \%\end{array}$ & $\begin{array}{l}300 \\
100.0 \%\end{array}$ & \multirow{5}{*}{23.629} & \multirow{5}{*}{6} & \multirow{5}{*}{0.001} \\
\hline & Anxiolytics & \begin{tabular}{|l|}
$\mathrm{n}$ \\
$\mathrm{hp}$
\end{tabular} & \begin{tabular}{|l|}
4 \\
$13.3 \%$ \\
\end{tabular} & \begin{tabular}{|l|l|}
130 \\
$43.3 \%$ \\
\end{tabular} & \begin{tabular}{|l|}
130 \\
$43.3 \%$ \\
\end{tabular} & \begin{tabular}{|l|}
300 \\
$100.0 \%$ \\
\end{tabular} & & & \\
\hline & Autogenic training & \begin{tabular}{|l} 
n \\
hp \\
\end{tabular} & & \begin{tabular}{|l|l|}
$\mathbf{1 5 0}$ \\
$\mathbf{5 0 . 0} \%$ \\
\end{tabular} & \begin{tabular}{|l|}
150 \\
$\mathbf{5 0 . 0} \%$ \\
\end{tabular} & \begin{tabular}{|l|l}
300 \\
$100.0 \%$
\end{tabular} & & & \\
\hline & Control & \begin{tabular}{|l|}
$n$ \\
$h p$ \\
\end{tabular} & \begin{tabular}{|l|}
50 \\
$16.7 \%$
\end{tabular} & \begin{tabular}{|l|}
100 \\
$33.3 \%$
\end{tabular} & \begin{tabular}{|l|}
150 \\
$50.0 \%$
\end{tabular} & \begin{tabular}{|l|}
300 \\
$100.0 \%$
\end{tabular} & & & \\
\hline & Total & $\begin{array}{l}\mathrm{n} \\
\mathrm{hp}\end{array}$ & \begin{tabular}{|l|}
100 \\
$8.3 \%$
\end{tabular} & \begin{tabular}{|l|l}
400 \\
$33.3 \%$
\end{tabular} & \begin{tabular}{|l|}
$\mathbf{7 0 0}$ \\
$\mathbf{5 8 . 3} \%$
\end{tabular} & \begin{tabular}{|l|}
1200 \\
$100.0 \%$
\end{tabular} & & & \\
\hline \multirow{5}{*}{$\begin{array}{l}\text { After } 4 \\
\text { months }\end{array}$} & Antidepressants & $\begin{array}{l}\mathrm{n} \\
\mathrm{hp}\end{array}$ & $\begin{array}{l}10 \\
3.3 \%\end{array}$ & \begin{tabular}{|l|l}
20 \\
$6.7 \%$
\end{tabular} & $\begin{array}{l}270 \\
90.0 \%\end{array}$ & $\begin{array}{l}300 \\
100.0 \%\end{array}$ & \multirow{5}{*}{14.707} & \multirow{5}{*}{6} & \multirow{5}{*}{0.023} \\
\hline & Anxiolytics & \begin{tabular}{|l}
$\mathrm{n}$ \\
$\mathrm{hp}$ \\
\end{tabular} & \begin{tabular}{|l|}
50 \\
$16.7 \%$ \\
\end{tabular} & \begin{tabular}{|l|l|}
30 \\
$10.0 \%$ \\
\end{tabular} & $\begin{array}{l}220 \\
73.3 \% \\
\end{array}$ & \begin{tabular}{|l|}
300 \\
$100.0 \%$
\end{tabular} & & & \\
\hline & Autogenic training & \begin{tabular}{|l|} 
n \\
hp
\end{tabular} & & \begin{tabular}{|l|l|}
$\mathbf{5 0}$ \\
$16.7 \%$
\end{tabular} & \begin{tabular}{|l|}
250 \\
$83.3 \%$
\end{tabular} & \begin{tabular}{|l|}
300 \\
$100.0 \%$
\end{tabular} & & & \\
\hline & Control & \begin{tabular}{|l}
$\mathrm{n}$ \\
$\mathrm{hp}$ \\
\end{tabular} & \begin{tabular}{|l|}
$\mathbf{5 0}$ \\
$16.7 \%$ \\
\end{tabular} & \begin{tabular}{|l|l|}
80 \\
$26.7 \%$ \\
\end{tabular} & \begin{tabular}{|l|}
170 \\
$\mathbf{5 6 . 7 \%}$ \\
\end{tabular} & \begin{tabular}{|l|}
300 \\
$100.0 \%$ \\
\end{tabular} & & & \\
\hline & Total & $\begin{array}{l}\mathrm{n} \\
\mathrm{hp}\end{array}$ & $\begin{array}{l}110 \\
9.2 \%\end{array}$ & $\begin{array}{l}180 \\
15.0 \%\end{array}$ & $\begin{array}{l}910 \\
75.8 \%\end{array}$ & $\begin{array}{l}1200 \\
100.0 \%\end{array}$ & & & \\
\hline
\end{tabular}

Legend:n - number of cases hp - horizontal percentage 